\title{
Dovile Troskovaite: Review of Mariusz Pawelec (ed.) Almanach Karaimski 2 (2013) 'Karaim Almanac', Wrocław: Bitik, 2013, 190 pages. ISSN 2300-8164.
}

Karaite studies in Eastern and Central Europe faces many important challenges. Firstly, the intensive research in the field that began in the interwar Poland was carried out by Karaites themselves, which led to the formation of a specific field of topics and approach to certain problems. I would argue that the main feature of interwar historiography, despite its relative quantity, was an intensive development of certain topics which served the community's need to establish itself as a separate ethnicity and gain recognition in the dominant society. As with other developing nationalisms, Karaite historiography had strong ideological implications, which have not yet been broadly analyzed. The presented volume is dedicated to the correspondence during the Interwar period of two prominent leaders in the Polish Karaite community, who were also the main creators of such an identity ideology and historiography. The relations between these people - Ananjasz Zajączkowski and Seraja Szapszał and their discussions in letters to each other, reveal their personal interests and their concerns about communal matters, but they also detail their personal life and express their individuality. These important sources can help us investigate the strategies used by prominent Karaite leaders in promoting a Karaite identity ideology in Karaite studies. The impact of this symbiosis is still undoubtedly felt in Karaite studies today. Moreover, the sources can be used to challenge the prevailing perception of the interwar period as a Golden Age in Eastern European Karaite history (which is true to a certain point), based on a refusal to see a more diverse picture of Karaite communal life of 
that time, including the competition that existed among two identity ideologies, the autocratic nature of the community's authorities, the suppression of critics of the leading figures in the community, the challenges of growing anti-Semitism, etc.

Despite the absence of an introduction to the published sources (57), which creates some difficulties in determining the quantitative qualities of the them (are these all known as preserved letters written by a particular person to Szapszal? Where are the original sources are stored? Have they been published previously? etc.), this does not change the fact that they are extremely important for investigating the history of the Polish Karaite community in the first half of the $20^{\text {th }}$ century, and for revealing the relationship between the community's elites, and the formation of Szapszal's authority for certain Karaite groups and for the community as a whole.

The publication of sources is supplemented by several articles revealing biographical details about each of the correspondents, which serves as an introduction to the sources that follow. Despite the fact that the above-mentioned persons were well-known Karaite leaders, not much is known about their lives. The only exception is the biography of Szapszal, which has been reconstructed in detail by a number of authors. ${ }^{1}$ However, in most existing studies, he is depicted with great enthusiasm and a fascination for his personality and activities, which makes most of these biographies a manifestation of Szapszal's cult among Karaites, rather than a scientific analysis of his life. For this reason, reference to studies on this topic must be treated with caution. The same can be said about

\footnotetext{
To mention some: Pawelec M., Seraja Szapszał i jego wkład w polską orientalistykę, in: Awazymyz, 2012, No. 1 (34), p. 19 [http://www.awazymyz.karaimi.org/zeszyty/item/22seraja-szapszal-i-jego-wklad-w-polska-orientalistyke, žr. 201202 21]; Zagreckaite A., Karaimų kultūros puoselètojas, in: Voruta, 1998 o6 o6, p. 10; Zemlickas G., Baltasis likimo žirgas raudona uodega, in: Mokslo Lietuva, 2012 01 26, p. 1, 6-7;02 09, p. 6-7; 02 23, p. 6-7; 03 22, p. 6-7; 04 05, p. 6-7, 12; Гонсёровски С., Между Россией, Персией и Турцией. Жизнь и деятельност Сераи Шапшала в 1873-1927 г.г. (ištrauka), in: Караимские вести, № 4 (102), 2011, р. 18; Гулиев В., Шапшал - азербайджановед, или наши братья - караимы (ištrauka), in: Караимские вести, № 4 (102), 2011, c. 19; Петров-Дубинский О., О наградах и гражданских чинах С. М. Шапшала, in: Караимские вести, № 4 (102), 2011, р. 26; Петров-Дубинский О., С. М. Шапшал в Персии: Путешествие по «шапшаловским» местам 100 лет спустя, in: Караимские вести, № 6 (87), 2008; Петров-Дубинский О., С. М. Шапшал - учёный, дипломат, духовный лидер караимского народа к 50-летию со дня смерти, in: Караимские вести, № 4 (102), 2011, p. 6, etc.
} 
several autobiographies composed by Szapszał himself, which are available in the Manuscript section of the Wroblewski Library of the Lithuanian Academy of Sciences and Lithuanian Central Historical Archive. These autobiographies were addressed to different institutions, and aimed to present Szapszał for different professional position, which meant that they had to be appropriate and impeccable in order to confirm his good reputation and help him achieve his goals.

The biography of Szapszal, presented in this volume by M. Pawelec can be treated as one of the better reconstructions of the activities of this prominent Karaite leader and provides a comprehensive picture of his personality. However, an analysis of important controversial facts in Szapszal's biography (possible participation in killings during the Persian revolution in 1905-1907, or spying on the side of the Russian Empire, not to mention more depicted in the Karaite $\operatorname{press}^{2}$ ) could provide a broader picture of the Karaite leader and contribute to a deconstruction of his heroic myth in the Karaite community, which was visible in the interwar period and plays an important role today as well, and could help reveal the mechanisms by which his biography was constructed. ${ }^{3}$ Pawelec should also be more cautious about some facts about Szapszał's life, and consider the construction of his biography as part of the public relations efforts of both the community and Szapszał himself. Due to this, I would not agree with author when he speaks about Szapszał being concerned with "gathering exhibits related to the history and culture of the smallest Turkic nation"4 - such a claim was very enthusiastically promoted by Szapszał himself, but the exhibition he sought to establish was intended for ideological purposes. The objects were indeed gathered by him, but they should be attributed to Turkish, Persian, and Azerbaijani, rather than Karaite, heritage.

Other texts published in this volume focus on the personality and activities of Ananiasz Zajączkowski. However, they sometimes create an idealized picture of this important Karaite leader and scholar, which says more about the attitude to this person and his activities among the Karaites today, than

2 Протест против кандидатуры С. М. Шапшала, in: Караимская жизнь, vol. 7, 1911, p. 117-118.

3 On negative opinions and accusations directed at Szapszał, see: Протест против кандидатуры С. М. Шапшала, Караимская жизнь, 1911, vol. 7, p. 117-118.

4 Pawelec M., Listy do Wilna. Seraja Szapszał jako korespondent AnaniaszaZajączkowskiego, Almanach Karaimski 2, 2013, p. 29. 
reveal his role in the interwar period and the community of that time. ${ }^{5}$ This might be the reason for not paying relevant attention to the personal relations between Szapszał and Zajączkowski, especially when it comes to issues, such as the publishing of Myśl Karaimska or organizing activities of the Society of the Lovers of Karaite History and Literature. One would expect discussion on the role of Zajączkowki in the publishing the Myśl Karaimska and some response to the critical assesment by Szymon Szyszman of the very marginal role of Zajączkowski in publishing the journal ${ }^{6}$ - especially since it was not until after Szapszal was appointed to the position of Polish Karaite hacham in 1928 (elected in 1927) that Zajączkowski became the editor of Myśl Karaimska and a board member of the Society of the Lovers of Karaite History and Literature; moreover, he was ordained in 1929 as hazzan by Szapszal himself and had to implement his duties in accordance with Szapszal's directions.7 The article lacks a presentation and analysis of the correspondence between Szapszał and Zajączkowski, and the above-mentioned issues are not revealed by the author, M. E. Zajączkowska-Łopatto.

Unlike other articles published in this volume, the research by M. Pawelec tries to analyse the correspondence between Szapszał and Zajączkowski. Perhaps the thesis raised by S. Szyszman on the relations between the two editors of the Myśl Karaimska makes sense? As a quotation from their correspondence in 1933 shows, Szapszal had to decide upon the font and image for the journal's title page - Zajączkowski did not take this decision, leaving it to the latter. One can ask what was the real role of Zajączkowski in editing the journal? Although the article does not go into a thorough analysis of this problem, it can be researched using the published correspondence between these two Karaites. One of the most important issues revealed by the author is the attitude of Szapszal to the content of the journal, and especially to the question of Karaite relations with Jewish tradition. This aspect provides new and interesting insights on how the content of the journal was organized, suggesting the

5 ZAJĄCZKOWSKA-ŁopatTo M. E., Listy Ananiasza Zajączkowskiego do Jego Ekscelencji Hadży Seraji Chana Szapszała, Almanach Karaimski 2, 2013, p. 6-10.

6 Szyszman Sz., Przywódca Duchowy Karaimów czy Marnotrawca Ich Dziejowego Dorobku Kulturalnego?, in: Ameryka-Echo, No. 39-40, Chicago, 1966, p. 10.

7 M. E. Zajączkowska-Łopatto quoted a letter by Szapszał where he states this very clearly. See: ZajączKowska-Łopatto M. E., Listy Ananiasza Zajączkowskiego do Jego Ekscelencji Hadży Seraji Chana Szapszała, Almanach Karaimski 2, 2013, p. 10; see also Urzeczeni Orientem. Listy profesora Ananiasza Zajączkowskiego do profesora Tadeusza Kowalskiego. 1925-1948, ed. T. MAJDA, Warszawa. Wydawnictwo Agade, 2013. 
need for more in-depth research on the ideological role of the magazine and its impact on the community's self-perception.

The text by Anna Sulimowicz reflects much on the biography of Aleksander Mardkowicz, as well as his literary works and community activities. It must be stressed that the Mardkowicz's biography has never been broadly investigated by researchers, and this article puts light on this topic. It is very rich in new facts, and provides important information that contributes significantly to Karaite studies. But in order to better understand Mardkowicz's intentions, the importance of his activities, and their impact on the community, they need to be analyzed from a broader perspective - with regard to relations with the other above-mentioned persons in the Karaite cultural and communal elite, the sharing and spread of their individual, as well as commonly-held ideas and goals. The author of the article describes the exchange of opinions on the question of publishing the journal Myśl Karaimska and its content, which served the above-mentioned purposes, but the reader can only assume the possible tensions between the publishers and editors of two Karaite newspapers Myśl Karaimska and Karay Awazy, and the different attitudes and perspectives that existed in the Karaite press, and how they were perceived by these people. However, the article seems to focus more on the personality of Mardkowicz than on his relations with Zajączkowski and/or Szapszal, and its analysis, although some very interesting and important issues from their written communication are revealed, could go deeper. ${ }^{8}$

Undoubtedly, the presented volume is a great contribution to Karaite studies in the region. It offers new sources for academic use, and encourages discussion on various topics. It is the second volume of Almanach Karaimski, which is a new and long-awaited platform for academic research in the field of Karaite studies.

8 The discussion on mixed marriages of Karaites and Tatars, see: Sulimowicz A., Listy do Łucka. Aleksander Mardkowicz jako adresat korespondencji Ananjasza Zajączkowskiego, Almanach Karaimski 2, 2013, p. 54-55. 